\title{
PENGARUH E - SERVICE QUALITY TERHADAP KEPUASAN PELANGGAN PENGGUNA APLIKASI EMOS (ENSEVAL MOBILE ORDER SYSTEM) PADA PT. ENSEVAL PUTERA MEGATRADING, TBK CABANG SAMARINDA
}

\author{
Titik Yuliana ${ }^{1}$ \\ Eddy Soegiarto ${ }^{2}$ \\ Adisthy Shabrina Nurqamarani ${ }^{3}$
Fakultas Ekonomi Universitas 17 Agustus 1945 Samarinda
Jl. Ir. H. Juanda No. 80, 75124, Indonesia
1yulianatitik23@gmail.com

\begin{abstract}
This study aims to determine the effect of E-Service Quality which includes Efficiency, Reliability, Fullfilment, Privacy, Responsiveness and Contact on Customer Satisfaction on users of the EMOS Application (Enseval Mobile Order System). The basic theory used in this research is Marketing Management, E-Service Quality and Customer Satisfaction. The population in this study was 266 pharmacies and samples taken were 73 pharmacies with simple random sampling technique. Data collection was done by distributing online questionnaires using a Likert scale to measure each indicator of the independent and dependent variable. The analytical tool used is multiple linear regression.The results of the research on the f test show that the E-Service Quality variables which include Efficiency, Reliability, Fullfilment, Privacy, Responsiveness and Contact have a significant effect simultaneously (simultaneously) on Customer Satisfaction. The t test shows that the independent variables; reliability and contact affect customer satisfaction while the variables Efficiency, Fullfilment, Privacy and Responsiveness do not affect the customer satisfaction of users of the EMOS application (Enseval Mobile Order System).
\end{abstract}

Keywords: E-Servqual, customer satisfaction, EMOS application, service quality

\section{PENDAHULUAN}

Penggunaan internet semakin meningkat dari tahun ke tahun di Indonesia. Internet sudah merajai semua kalangan masyarakat, dengan internet segala sesuatunya menjadi lebih mudah, efisiensi pertukaran informasi yang lebih cepat. Pemanfaatan internet juga diimplementasikan dalam bisnis karena mengikuti perkembangan dimana saat ini kita hidup di era digital. Pemanfaatan internet saat ini sudah lebih jauh, bukan hanya untuk berkomunikasi tetapi juga untuk membeli barang, memesan transportasi hingga berbisnis dan berkarya. Era digital saat ini dimanfaatkan perusahaan untuk memperluas pemasaran produk dan memberikan kemudahan serta kenyamanan yang bertujuan untuk kepuasan pelanggan. Perusahaan yang melakukan inovasi salah satunya adalah 
PT. Enseval Putera Megatrading, Tbk yang merupakan perusahaan distributor farmasi yang sudah memiliki 49 cabang di Indonesia. Dengan melihat kondisi dimana penggunaan smartphone dan internet yang merata di Indonesia, mendorong PT. Enseval Putera Megatrading, Tbk untuk memberikan cara alternatif bagi pelanggan untuk melakukan pemesanan dan mendapatkan informasi yang dibutuhkan hanya dengan menggunakan aplikasi EMOS (Enseval Mobile Order System). Permasalahan utama dalam penelitian ini adalah penggunaan aplikasi EMOS yang belum merata pada lini apotek PT. Enseval Putera Megatrading cabang Samarinda. Dalam sistem pemesanan produk PT. Enseval Putera Megatrading dapat dilakukan dengan cara order melalui salesman, menghubungi customer care 1500095 dan melalui aplikasi EMOS. Aplikasi EMOS memiliki kelebihan dapat melakukan pemesanan dengan cepat dan mudah karena dapat melakukan pemesanan dengan smartphone dan dimana saja, serta memberikan informasi kepada pelanggan, namun EMOS juga memiliki kelemahan yaitu EMOS hanya dapat di akses dengan smartphone berbasis android, adapun permasalahan yang terjadi yaitu keluhan pelanggan antara lain sistem EMOS yang mengalami gangguan sehingga tidak dapat di akses, keterlambatan pengiriman, kesalahan pengiriman barang, sering terjadi kekosongan barang, tidak mendapat poin dan sering mengalami error saat transaksi. Dalam implementasinya ternyata tidak semua pelanggan memilih untuk menggunakan aplikasi EMOS sehingga penggunaan EMOS sampai saat ini belum merata. Sementara yang menjadi target PT. Enseval Putera Megatrading, Tbk cabang Samarinda adalah agar semua pelanggan pada lini apotek menggunakan aplikasi EMOS yang dirasa lebih efektif dan efisien dalam pelayanan.Penerapan pelayanan daripada EMOS PT. Enseval Putera Megatrading, Tbk cabang Samarinda mengimplementasikan eservice quality yaitu efisiensi adalah EMOS memberikan kemudahan dan efisien dalam melakukan transaksi pemesanan. Reliabilitas yaitu EMOS memiliki keakuratan teknis dalam pelayanan transaksi aplikasi EMOS. Fulfillment adalah memenuhi pelayanan sesuai dengan apa yang dijanjikan atau ditawarkan dalam aplikasi EMOS. Privasi adalah EMOS menjaga dan melindungi data terkait bersifat privacy pelanggan. Daya tanggap (responsiveness) adalah menangani permasalahan atau keluhan pelanggan dengan cepat. Kontak adalah dengan memberi layanan customer service yang dapat dihubungi oleh pelanggan. 
Kepuasan pelanggan merupakan indikator keberhasilan suatu pelayanan dimana pelanggan memberikan nilai apakah pelayanan yang diberikan sudah sesuai dengan harapan atau tidak yang dipengaruhi oleh dimensi e-servqual.

\section{KERANGKA TEORITIS}

\section{Manajemen Pemasaran}

Manajemen menurut Nawawi (2011:23), Manajemen adalah proses pengaturan, pengurusan dan pengelolaan dengan memanfaatkan orang lain dalam pengelolaan sumber daya untuk pencapaian suatu tujuan.

Pemasaran menurut Suharno (2017:4), Pemasaran diartikan sebagai proses dimana perusahaan menciptakan nilai untuk pelanggan dan membangun hubungan pelanggan yang kuat dalam rangka mendapatkan manfaat atau keuntungan.

Manajemen Pemasaran menurut Alma (2013:130), Manajemen pemasaran adalah kegiatan menganalisa, merencanakan, mengimplementasi, dan mengawasi segala kegiatan (program), guna memperoleh tingkat pertukaran yang menguntungkan dengan pembeli sasaran dalam rangka mencapai tujuan organisasi.

\section{E-Service Quality}

$\begin{array}{ccc}\text { Pengertian } & \text { E-Service } & \text { Quality } \\ \text { menurut Tjiptono } & (2017: 202) & \text { adalah }\end{array}$

model kualitas jasa yang paling komprehensif dan integratif dikarenakan dimensi tersebut relevan dan secara menyeluruh memenuhi kebutuhan untuk mengevaluasi kualitas jasa elektronik dan terdapat enam dimensi dari kualitas jasa $e$ service yaitu:

a. Efisiensi, yaitu kemampuan pelanggan untuk mengakses website, mencari produk yang diinginkan dan informasi yang berkaitan dengan produk tersebut dan meninggalkan situs bersangkutan dengan upaya minimal.

b. Reliabilititas, berkenaan dengan fungsionalitas teknis situs bersangkutan, khususnya sejauh mana situs tersebut tersedia dan berfungsi sebagaimana mestinya.

c. Fulfillment, mencakup akurasi janji layanan, ketersediaan stok produk dan pengiriman yang sesusai dengan waktu yang dijanjikan.

d. Privasi, berupa jaminan bahwa data perilaku berbelanja tidak akan diberikan kepada pihak lain manapun dan bahwa informasi kartu kredit pelanggan terjamin keamanannya.

e. Daya tanggap (responsiveness), merupakan kemampuan pengecer online untuk memberikan informasi yang tepat kepada pelanggan sewaktu timbul masalah, memiliki mekanisme untuk 
menangani pengembalian produk dan menyediakan garansi online.

f. Kontak (contact), mencerminkan kebutuhan pelanggan untuk bisa berbicara dengan staf layanan pelanggan secara online atau melalui telepon (dan bukan berkomunikasi dengan mesin)

\section{Kepuasan Pelanggan}

Menurut Tjiptono (2017:287) respon pelanggan terhadap evaluasi persepsi atas perbedaan antara harapan awal sebelum pembelian (atau standar kinerja lainnya) dan kinerja aktual produk sebagaimana dipersepsikan setelah memakai produk bersangkutan.

\section{METODE PENELITIAN}

\section{Definisi Operasional}

1. Efisiensi (X1) adalah bentuk layanan kepada pelanggan pengguna aplikasi EMOS dengan memberikan kemudahan dan efisien dalam bertransaksi. Adapun indikatornya:
a. Tidak ada gangguan saat transaksi
b. Mudah menemukan produk
c. Meninggalkan halaman dengan cepat

2. Reliabilitas (X2) adalah bentuk layanan kepada pelanggan pengguna EMOS berupa keakuratan teknis dari aplikasi. Adapun indikatornya:
a. Produk sama dengan pesanan
b. Tidak terjadi perubahan harga
c. Memiliki fitur lengkap dan jelas

3. Fullfilment (X3) adalah benruk layanan kepada pelanggan pengguna EMOS dengan pemenuhan pelayanan sesuai dengan yang dijanjikan. Adapun indikatornya:

a. Melayani sesuai dengan yang ditawarkan

b. Ketersediaan stok

c. Pengiriman tepat waktu

4. Privasi (X4) adalah bentuk layana kepada pelanggan pengguna aplikasi EMOS dengan menjaga dan melindungi data terkait bersifat privacy pelanggan. Adapun indikatornya:
a. Melindungi informasi pelanggan
b. Transaksi aman dan terpercaya
c. Tidak ada kebocoran data

5. Daya tanggap (X5) adalah bentuk layanan kepada pelanggan pengguna EMOS dengan kecepatan dalam menangani permasalahan dan keluhan pelanggan. Adapun indikatornya:

a. Menangani retur dengan cepat

b. Menangani masalah/keluhan dengan segera

c. Mengkonfirmasi pesanan dengan cepat

6. Kontak (X6) adalah bentuk layanan kepada pelanggan pengguna EMOS dengan memberikan informasi berisi kontak yang dapat dihubungi atau diakses pelanggan.Adapun indikatornya: 
a. Menyediakan kontak untuk menyampaikan masalah/keluhan

b. Memiliki customer service yang tersedia secara online

c. Terdapat alamat kantor

7. Kepuasan pelanggan (Y) merupakan perasaan yang timbul setelah mengevaluasi pemakaian produk atau jasa. Adapun indikatornya sebagai berikut:

a. Puas dengan kecepatan pelayanan EMOS

b. Puas dengan kemudahan dalam penggunaan EMOS

c. Puas dengan informasi yang akurat pada EMOS

Teknik Pengumpulan Data, Populasi, dan Sampel

Metode penelitian yang digunakan dalam penelitian ini adalah kuantitatif yang dapat diartikan sebagai metode penelitian yang berlandaskan pada filsafat positivisme digunakan untuk meneliti pada populasi atau sampel tertentu, teknik pengambilan sampel pada umumnya dilakukan secara random, pengumpulan data menggunakan instrument penelitian, analisis data bersifat kuantitatif/statistik dengan tujuan untuk menguji hipotesis yang telah ditetapkan. Adapun variabel yang diteliti adalah Efisiensi, Reliabilitas, Fullfilment, Privasi, Daya tanggap dan
Kontak (X) terhadap Kepuasan Pelanggan (Y).

Metode pengumpulan data dalam penilitian ini dengan memberikan kuesioner online kepada pengguna aplikasi EMOS dengan populasi 266 apotek sedangkan sampel yang menjadi responden dalam penelitian ini sebanyak 73 Apotek dengan Probability Sampling menggunakan teknik Simple Random Sampling. Analisis data yang digunakan dalam penelitian ini menggunakan regresi linear berganda yang sebelumnya dilakukan uji validitas dan reliabilitas.

\section{HASIL DAN PEMBAHASAN}

\section{Uji Validitas}

Uji Validitas digunakan untuk mengetahui kesamaan antara data yang dikumpul dengan data yang sesungguhnya terjadi pada obyek yang diteliti, sehingga dapat diperoleh hasil yang valid. Valid berarti instrument tersebut dapat digunakan untuk mengukur apa yang seharusnya diukur.

\section{Tabel 1:Uji Validitas}




\begin{tabular}{|c|c|c|c|c|}
\hline $\begin{array}{l}\mathbf{N} \\
\mathbf{o}\end{array}$ & Variabel & $\mathbf{r}_{\text {hitung }}$ & $\mathbf{r}_{\text {tabel }}$ & $\begin{array}{c}\text { Keterang } \\
\text { an }\end{array}$ \\
\hline \multirow{4}{*}{1} & Efisiensi $\left(X_{1}\right)$ & & & \\
\hline & $\mathrm{X} 1.1$ & 0.653 & 0.2303 & Valid \\
\hline & $\mathrm{X} 1.2$ & 0.657 & 0.2303 & Valid \\
\hline & $\mathrm{X} 1.3$ & 0.598 & 0.2303 & Valid \\
\hline \multirow{4}{*}{2} & Reliabilitas ( $\mathbf{X}$ & & & \\
\hline & $\mathrm{X} 2.1$ & 0.703 & 0.2303 & Valid \\
\hline & $\mathrm{X} 2.2$ & 0.669 & 0.2303 & Valid \\
\hline & $\mathrm{X} 2.3$ & 0.505 & 0.2303 & Valid \\
\hline \multirow{4}{*}{3} & Fullfilment $\left(\mathrm{X}_{3}\right.$ & & & \\
\hline & $\mathrm{X} 3.1$ & 0.542 & 0.2303 & Valid \\
\hline & $\mathrm{X} 3.2$ & 0.670 & 0.2303 & Valid \\
\hline & X3.3 & 0.693 & 0.2303 & Valid \\
\hline
\end{tabular}

\section{Uji Reliabilitas}

Uji reliabilitas adalah untuk mengukur sejauh mana suatu alat pengukuran dapat memberikan hasil yang reliabel bila dilakukan dalam waktu yang berbeda pada obyek yang sama. Dari analisis diperoleh hasil seperti pada tabel sebagai berikut :

\section{Tabel 2 : Uji Reliabilitas}

\begin{tabular}{|c|c|c|c|c|}
\hline o & Variabel & $\begin{array}{r}\mathrm{r} \\
\text { alpha }\end{array}$ & $\begin{array}{r}\text { r } \\
\text { kritis }\end{array}$ & Keterangan \\
\hline 1 & Efisiensi (X1) & 0,755 & 0,60 & Reliabel \\
\hline 2 & $\begin{array}{l}\text { Reliabilitas } \\
\text { (X2) }\end{array}$ & 0,793 & 0,60 & Reliabel \\
\hline 3 & $\begin{array}{l}\text { Fullfilment } \\
\text { (X3) }\end{array}$ & 0,959 & 0,60 & Reliabel \\
\hline 4 & Privasi (X4) & 0,789 & 0,60 & Reliabel \\
\hline 5 & $\begin{array}{l}\text { Daya Tanggap } \\
\text { (X5) }\end{array}$ & 0,771 & 0,60 & Reliabel \\
\hline 6 & Kontak (X6) & 0,822 & 0,60 & Reliabel \\
\hline 7 & $\begin{array}{l}\text { Kepuasan } \\
\text { Pelanggan (Y) }\end{array}$ & 0,826 & 0,60 & Reliabel \\
\hline
\end{tabular}

\section{Regresi Linier Berganda}

Regresi linear berganda dilakukan untuk mengetahui sejauh mana variabel bebas mempengaruhi variabel terikat. Dalam penelitian ini yang menjadi variabel terikat adalah kepuasan pelanggan sedangkan yang menjadi variabel bebas adalah Efisiensi, Reliabilitas, Fulfillment, Privasi, Daya Tanggap dan Kontak. Model Hubungan kepuasan pelanggan dengan variabel - variabel tersebut dapat disusun dalam menggunakan rumus Sugiyono (2016:211) sebagai berikut :

\begin{tabular}{|c|c|c|c|c|}
\hline $\begin{array}{l}\mathbf{N} \\
\mathbf{o}\end{array}$ & Variabel & $\mathbf{r}_{\text {hitung }}$ & $\mathbf{r}_{\text {tabel }}$ & $\begin{array}{c}\text { Keterang } \\
\text { an }\end{array}$ \\
\hline \multirow{4}{*}{4} & Privasi $\left(\mathrm{X}_{4}\right)$ & & & \\
\hline & $\mathrm{X} 4.1$ & 0.677 & 0.2303 & Valid \\
\hline & $\mathrm{X} 4.2$ & 0.611 & 0.2303 & Valid \\
\hline & $\mathrm{X} 4.3$ & 0.644 & 0.2303 & Valid \\
\hline \multirow{4}{*}{5} & Daya Tanggap & & & \\
\hline & $\mathrm{X} 5.1$ & 0.581 & 0.2303 & Valid \\
\hline & $\mathrm{X} 5.2$ & 0.524 & 0.2303 & Valid \\
\hline & $\mathrm{X} 5.3$ & 0.499 & 0.2303 & Valid \\
\hline \multirow{4}{*}{6} & Kontak $\left(\mathbf{X}_{6}\right)$ & & & \\
\hline & $\mathrm{X} 6.1$ & 0.635 & 0.2303 & Valid \\
\hline & $\mathrm{X} 6.2$ & 0.426 & 0.2303 & Valid \\
\hline & X6.3 & 0.660 & 0.2303 & Valid \\
\hline \multirow{4}{*}{7} & Kepuasan Pel & & & \\
\hline & $\mathrm{Y} 1$ & 0.608 & 0.2303 & Valid \\
\hline & Y2 & 0.579 & 0.2303 & Valid \\
\hline & Y3 & 0.631 & 0.2303 & Valid \\
\hline
\end{tabular}

\section{Tabel 3 : Regresi Linear Berganda}




\begin{tabular}{|c|c|c|c|c|c|}
\hline \multirow[t]{2}{*}{ Model } & \multicolumn{2}{|c|}{$\begin{array}{l}\text { Unstandardiz } \\
\text { ed } \\
\text { Coefficients }\end{array}$} & \multirow[t]{2}{*}{$\begin{array}{l}\text { Standar } \\
\text { dized } \\
\text { Coeffic } \\
\text { ients }\end{array}$} & \multirow[t]{2}{*}{ 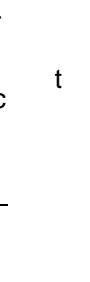 } & \multirow[t]{2}{*}{$\begin{array}{l}\mathrm{Si} \\
\mathrm{g}\end{array}$} \\
\hline & B & $\begin{array}{l}\text { Std. } \\
\text { Error }\end{array}$ & & & \\
\hline $\begin{array}{l}1 \\
\text { (Constant) }\end{array}$ & $\begin{array}{r}3,99 \\
6\end{array}$ & 1,973 & & 2,025 & ,047 \\
\hline X1_Efisiensi &,- 003 & , 107 &,- 003 &,- 030 & ,976 \\
\hline X2_Reliabilitas & ,316 & ,102 &, 350 & 3,085 & ,003 \\
\hline X3_Fullfilment & 057 & ,103 & ,066 &, 549 &, 585 \\
\hline X4_Privasi &,- 118 &, 117 &,- 122 & $-1,001$ & ,320 \\
\hline X5_Daya_Tanggap & ,118 & ,156 & ,097 & ,756 & ,452 \\
\hline X6_Kontak & 313 & ,112 & ,328 & 2,795 & ,007 \\
\hline
\end{tabular}

a. Dependent Variable:

Y_Kepuasan_Pelanggan

Berdasarkan tabel 3 diperoleh persamaan regresi efisiensi $X_{1}$, reliabilitas $X_{2}$, fullfilment $\mathrm{X}_{3}$, privasi $\mathrm{X}_{4}$, daya tanggap $\mathrm{X}_{5}$ dan kontak $\mathrm{X}_{6}$ terhadap kepuasan pelanggan $\mathrm{Y}$ adalah sebagai berikut $: \mathrm{Y}=$ $3,996-0,003 \mathrm{X}_{1}+0,316 \mathrm{X}_{2}+0,057 \mathrm{X}_{3}-$ $0,118 \mathrm{X}_{4}+0,118 \mathrm{X}_{5}+0,313 \mathrm{X}_{6}+e$

Berdasarkan hasil tersebut diperoleh hasil persamaan regresi linear berganda sebagai berikut :

a. Nilai konstanta 3,996 didapat dari output spss yang dipengaruhi oleh variabel bebas kepuasan pelanggan yang terdiri dari efisiensi, reliabilitas, fullfilment, privasi, daya tanggap dan kontak. Dengan demikian pengaruh variabel bebas tersebut terhadap kepuasan pelanggan tidak akan mengalami perubahan.

b. Pengaruh efisiensi $\mathrm{X}_{1}$ terhadap kepuasan pelanggan Y.Berdasarkan hasil analisis pada tabel 3 diketahui bahwa nilai koefisien variabel efisiensi $\mathrm{X}_{1}$ sebesar 0,003 dan bertanda negatif, hal ini menunjukkan bahwa efisiensi mempunyai hubungan yang berlawanan arah yang artinya setiap kenaikan satu satuan variabel efisiensi maka akan mengalami penurunan sebesar 0,003.

c. Pengaruh reliabilitas $\mathrm{X}_{2}$ terhadap kepuasan pelanggan Y.Berdasarkan hasil analisis pada tabel 3 diketahui bahwa variabel reliabilitas $X_{2}$ sebesar 0,316 yang artinya setiap kenaikan satu satuan variabel reliabilitas akan mengalami kenaikan sebesar 0,316.

d. Pengaruh fullfilment $\mathrm{X}_{3}$ terhadap kepuasan pelanggan Y.Berdasarkan hasil analisis pada tabel 3 diketahui bahwa variabel fullfilment $\mathrm{X}_{3}$ sebesar 0,057 yang artinya setiap kenaikan satu satuan variabel fullfilment akan mengalami kenaikan sebesar 0,057.

e. Pengaruh privasi $\mathrm{X}_{4}$ terhadap kepuasan pelanggan Y. Berdasarkan hasil analisis pada tabel 3 diketahui bahwa nilai koefisien variabel privasi $\mathrm{X}_{4}$ sebesar 0,118 dan bertanda negatif, hal ini menunjukkan bahwa privasi 
mempunyai hubungan yang berlawanan arah yang artinya setiap kenaikan satu satuan variabel privasi maka akan mengalami penurunan sebesar 0,118 .

f. Pengaruh daya tanggap $X_{5}$ terhadap kepuasan pelanggan Y.Berdasarkan hasil analisis pada tabel 3 diketahui bahwa variabel daya tanggap $\mathrm{X}_{5}$ sebesar 0,118 yang artinya setiap kenaikan satu satuan variabel daya tanggap akan mengalami kenaikan sebesar 0,118 .

g. Pengaruh kontak $\mathrm{X}_{6}$ terhadap kepuasan pelanggan Y. Berdasarkan hasil analisis pada tabel 3 diketahui bahwa variabel Kontak $\mathrm{X}_{6}$ sebesar 0,313 yang artinya setiap kenaikan satu satuan variabel kontak akan mengalami kenaikan sebesar 0,313.

\section{Uji T}

Menurut Ghozali (2009:88), uji statistik $\mathrm{t}$ pada dasarnya menunjukkan seberapa jauh pengaruh satu variabel independen secara individual dalam menerangkan variabel dependen. Pengujian dilakkan dengan menggunakan tingkat signifikansi $0,05(\alpha=5 \%)$.

Tabel 4 : Uji T

\begin{tabular}{lll} 
Model & $\begin{array}{l}\text { Standar } \\
\text { Unstandardiz } \\
\text { ed }\end{array}$ & $\begin{array}{l}\text { dized } \\
\text { Coeffici }\end{array}$ \\
Coefficients & $\begin{array}{l}\text { ents } \\
\text { C }\end{array}$ \\
\cline { 2 - 3 } & Std. & B \\
& Error & e \\
& & t \\
& & a
\end{tabular}

\begin{tabular}{|c|c|c|c|c|c|}
\hline 1 (Constant) & $\begin{array}{r}3,99 \\
6\end{array}$ & 1,973 & & 2,025 & ,047 \\
\hline X1_Efisiensi & , 003 & 107 &,- 003 &,- 030 & ,976 \\
\hline X2_Reliabilitas & ,316 & ,102 & ,350 & 3,085 &, 003 \\
\hline X3_Fullfilment & ,057 & ,103 & ,066 &, 549 &, 585 \\
\hline X4_Privasi &, 118 & ,117 &,- 122 & $-1,001$ & ,320 \\
\hline X5_Daya_Tanggap &, 118 & ,156 &, 097 & ,756 & ,452 \\
\hline X6_Kontak & ,313 & ,112 & , 328 & 2,795 & ,007 \\
\hline \multicolumn{6}{|c|}{$\begin{array}{l}\text { a. Dependent Variable: } \\
\text { Y_Kepuasan_Pelanggan }\end{array}$} \\
\hline Berdasark & an & pada & tabel & 4 & \\
\hline
\end{tabular}

diketahui bahwa :

a. variabel efisiensi menunjukkan nilai $t_{\text {hitung }}$ sebesar $-0,030$ lebih kecil dari $t_{\text {tabel }}$ sebesar 1,66600 dengan signifikansi lebih besar dari 0,05 . Disimpulkan bahwa variabel efisiensi $\mathrm{X}_{1}$ tidak berpengaruh signifikan terhadap kepuasan pelanggan $\mathrm{Y}$.

b. Variabel reliabilitas menunjukkan nilai thitung sebesar 3,085 lebih besar dari $t_{\text {tabel }}$ sebesar 1,66600 dengan signifikansi lebih kecil dari 0,05. Disimpulkan bahwa variabel reliabilitas $\mathrm{X}_{2}$ berpengaruh signifikan terhadap kepuasan pelanggan $\mathrm{Y}$.

c. Variabel fullfilment menunjukkan nilai $t_{\text {hitung }}$ sebesar 0,549 lebih kecil dari $t_{\text {tabel }}$ sebesar 1,66600 dengan signifikansi lebih besar dari 0,05. Disimpulkan bahwa variabel $S$ fullfilment $\mathrm{X}_{3}$ tidak berpengaruh g signifikan terhadap kepuasan pelanggan $\mathrm{Y}$. 
d. Variabel privasi menunjukkan nilai $t_{\text {hitung }}$ sebesar $-1,001$ lebih kecil dari $t_{\text {tabel }}$ sebesar 1,66600 dengan signifikansi lebih besar dari 0,05. Disimpulkan bahwa variabel privasi $\mathrm{X}_{4}$ tidak berpengaruh signifikan terhadap kepuasan pelanggan Y.

e. Variabel daya tanggap menunjukkan nilai thitung sebesar 0,756 lebih kecil dari $\mathrm{t}_{\text {tabel }}$ sebesar 1,66600 dengan signifikansi lebih besar dari 0,05. Disimpulkan bahwa variabel daya tanggap $\mathrm{X}_{5}$ tidak berpengaruh signifikan terhadap kepuasan pelanggan Y.

f. Variabel kontak menunjukkan nilai $t_{\text {hitung }}$ sebesar 2,795 lebih besar dari $t_{\text {tabel }}$ sebesar 1,66600 dengan signifikansi lebih kecil dari 0,05. Disimpulkan bahwa variabel kontak $\mathrm{X}_{6}$ berpengaruh signifikan terhadap kepuasan pelanggan $\mathrm{Y}$.

\section{Uji F}

Menurut Ghozali (2009:88), uji statistik $\mathrm{F}$ pada dasarnya menunjukkan apakah semua model variabel independen atau bebas yang dimasukkan dalam model mempunyai pengaruh secara bersama sama terhadap variabel dependen atau terikat. Pengujian dilakukan dengan menggunakan tingkat signifikansi 0,05 ( $\alpha$ $=5 \%)$

\section{Tabel 5 : Uji F}

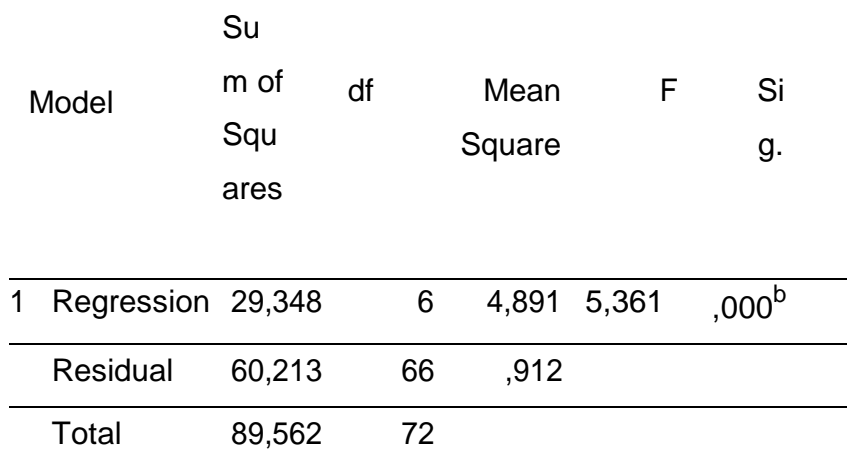

a. Dependent Variable: Y_Kepuasan_Pelanggan

b. Predictors: (Constant),

X6_Kontak, X1_Efisiensi,

X4_Privasi, X2_Reliabilitas,

X3_Fullfilment,

X5_Daya_Tanggap

Berdasarkan tabel 4 diketahui nilai $f_{\text {hitung }} 5,361$ lebih besar dari $f_{\text {tabel }} 2,23$ dengan nilai signifikasi 0,000 lebih kecil dari 0,05 sehingga signifikan. Dengan demikian dapat disimpulkan bahwa terdapat pengaruh positif dan signifikan secara bersama-sama antara variabel efisiensi $\mathrm{X}_{1}$, reliabilitas $\mathrm{X}_{2}$, fullfilment $\mathrm{X}_{3}$, privasi $\mathrm{X}_{4}$, daya tanggap $\mathrm{X}_{5}$ dan kontak $\mathrm{X}_{6}$ terhadap kepuasan pelanggan Y.

\section{Koefisien Determinasi $\left(\mathbf{R}^{2}\right)$}

Koefisiensi determinasi $\mathrm{R}^{2}$ digunakan untuk menentukan seberapa besar variabel independen dapat menjelaskan variabel dependen, maka perludiketahui nilai koefisiensi determinasi (Adjusted R-Square). Hasil uji determinasi Adjusted $\mathrm{R}^{2}$ sebagai berikut :

\section{Tabel 6 : Uji Determinasi R}

$\begin{array}{llrll}\text { Mod } & R & \text { R } & \text { Adjusted } & \text { Std. } \\ \text { el } & & \text { S } & \text { Error of } \\ & & \text { Square } & \text { Square } & \text { the } \\ & & & & \text { Estimate }\end{array}$


1

a. Predictors: (Constant),

X6_Kontak,

X1_Efisiensi, X4_Privasi,

$\mathrm{X} 2$ Reliabilitas,

X3_Fullfilment,

X5_Daya_Tanggap

Berdasarkan tabel 6 diketahui bahwa nilai koefisiensi determinasi $\left(\mathrm{R}^{2}\right)$ berada diantara $0-1$ atau $0<\mathrm{R}^{2}<1$. $\mathrm{R}^{2}$ sebesar 0,667 (66,7\%). Dengan nilai koefisien determinasi sebesar 0,267 ini menunjukkan bahwa dengan model regresi yang didapatkan dimana variabel bebas yaitu efisiensi $\mathrm{X}_{1}, \quad$ reliabilitas $\mathrm{X}_{2}$, fullfilment $\mathrm{X}_{3}$, privasi $\mathrm{X}_{4}$, daya tanggap $\mathrm{X}_{5}$ dan kontak $\mathrm{X}_{6}$ memilki pengaruh terhadap kepuasan pelanggan $\mathrm{Y}$ sebesar $66,7 \%$, sedangkan sisanya berhubungan dengan faktor lain atau variabel lain yang tidak termasuk dalam analisis regresi berganda.

\section{Korelasi (R)}

Koefisien korelasi $\mathrm{R}$ yang digunakan dalam mengetahui kuatnya hubungan antara variabel bebas dan terikat, maka adapun hasil uji koefisien korelasi R sebagai berikut :

\section{Tabel 7 : Uji Koefisien Korelasi R}

\begin{tabular}{llr} 
Model & R & R Square \\
\hline 1 & $.572^{\mathrm{a}}$ & .328
\end{tabular}

Berdasarkan tabel 6 diketahui hasil koefisien kolerasi menunjukkan bahwa nilai $\mathrm{R}=0,572$ yang berarti bahwa hubungan antara variabel independen efisiensi $\mathrm{X}_{1}$, reliabilitas $\mathrm{X}_{2}$, fullfilment $\mathrm{X}_{3}$, privasi $\mathrm{X}_{4}$, daya tanggap $\mathrm{X}_{5}$ dan kontak $\mathrm{X}_{6}$ terhadap variabel terikat kepuasan pelanggan $\mathrm{Y}$ terletak diantara 0,40 - 0,599 yang artinya mempunyai kategori hubungan Sedang.

\section{PEMBAHASAN}

Pengaruh Efisiensi (X1) terhadap kepuasan pelanggan pengguna aplikasi EMOS.

Variabel efisiensi $\left(\mathrm{X}_{1}\right)$ dengan nilai thitung sebesar -0,030 lebih kecil dari $t_{\text {tabel }}$ 1,66600, dan diperoleh nilai signifikan sebesar 0,976 dimana nilai tersebut lebih besar dari nilai sig 0,05 yang artinya variabel efisiensi tidak berpengaruh signifikan (parsial) terhadap kepuasan pelanggan pengguna aplikasi EMOS.

Hasil penelitian tersebut menunjukkan bahwa variabel efisiensi pada aplikasi EMOS tidak berpengaruh secara parsial terhadap kepuasan pelanggan. Hal ini menunjukkan bahwa pelayanan aplikasi EMOS belum maksimal dalam memberikan kemudahan kepada pelanggan dimana pelanggan memiliki permasalahan pada saat mengakses EMOS seperti error, loading lambat dan tidak dapat melakukan $\log$ in, selain permasalahan dari EMOS sendiri terdapat faktor lain yang berhubungan dengan jaringan internet yang mungkin 
tempat dimana pelanggan mengakses EMOS tidak didukung jaringan internet yang baik. Selain itu dalam pencarian produk yang diinginkan pelanggan mengalami kesulitan karena tidak adanya fitur pencarian produk pada halaman EMOS, pelanggan harus memilih menu order terlebih dahulu agar dapat menemukan produk yang dicari.

\section{Pengaruh Reliabilitas ( $\left.\mathbf{X}_{2}\right)$ Terhadap} Kepuasan Pelanggan Pengguna Aplikasi EMOS

Variabel reliabilitas $\left(\mathrm{X}_{2}\right)$ dengan nilai thitung sebesar 3,085 lebih besar dari $t_{\text {tabel }} 1,66600$, dan diperoleh nilai signifikan sebesar 0,003 dimana nilai tersebut lebih kecil dari nilai sig 0,05 yang artinya variabel reliabilitas berpengaruh signifikan (parsial) terhadap kepuasan pelanggan pengguna aplikasi EMOS. EMOS memberikan keakuratan dalam pelayanan pelanggan. Keakuratan yang paling penting dan lebih sensitif adalah harga, dimana EMOS terhubung dengan sistem sehingga tidak terjadi perubahan harga setelah bertransaksi, selain memiliki tampilan fitur yang lengkap dan jelas secara teknis pelayanan EMOS selalu melakukan kontrol sebelum pesanan sampai kepada pelanggan dan memastikan bahwa produk sesuai dengan permintaan.
Pengaruh Fullfilment $\left(\mathbf{X}_{3}\right)$ Terhadap Kepuasan Pelanggan Pengguna Aplikasi EMOS

Variabel fullfilment $\left(\mathrm{X}_{3}\right)$ dengan nilai $\mathrm{t}$ hitung sebesar 0,549 lebih kecil dari t tabel 1,66600 , dan diperoleh nilai signifikan sebesar 0,585 dimana nilai tersebut lebih besar dari nilai sig 0,05 yang artinya variabel fullfilment tidak berpengaruh signifikan (parsial) terhadap kepuasan pelanggan pengguna aplikasi EMOS. Adanya kekosongan barang menjadi salah satu permasalahan kurangnya pelayanan. Pelanggan tidak dapat melihat stok sebelum melakukan check out sehingga dapat menimbulkan kekecewaan karena ternyata produk yang dibutuhkan tidak tersedia atau stok produk yang kurang. EMOS menginformasikan bahwa akan mengirimkan pesanan pada hari yang sama (same day) namun masih terdapat keterlambatan pengiriman. Keterlambatan ini dapat dikarenakan karena kurangnya armada pengiriman atau dikarenakan menunggu pesanan lain yang belum terfaktur.

\section{Pengaruh Privasi $\left(\mathbf{X}_{4}\right)$ Terhadap} Kepuasan Pelanggan Pengguna Aplikasi EMOS

Variabel privasi $\left(\mathrm{X}_{4}\right)$ dengan nilai $t_{\text {hitung }}$ sebesar -1,001 lebih kecil dari $t_{\text {tabel }}$ 1,66600, dan diperoleh nilai signifikan sebesar 0,320 dimana nilai tersebut lebih 
besar dari nilai sig 0,05 yang artinya variabel privasi tidak berpengaruh signikan (parsial) terhadap kepuasan pelanggan pengguna aplikasi EMOS. Hal ini menunjukan bahwa data pelanggan belum terlindungi secara maksimal. Diperkuat dengan beberapa keluhan pelanggan dimana pelanggan kehilangan poin yang tersimpan secara tiba-tiba padahal pelanggan tidak melakukan penukaran poin sekali.

\section{Pengaruh Daya Tanggap $\left(\mathbf{X}_{5}\right)$ Terhadap} Kepuasan Pelanggan Pengguna Aplikasi EMOS

Variabel daya tanggap $\left(\mathrm{X}_{5}\right)$ dengan nilai thitung sebesar 0,756 lebih kecil dari $\mathrm{t}_{\text {tabel }} 1,66600$, dan diperoleh nilai signifikan sebesar 0,452 dimana nilai tersebut lebih besar dari nilai sig 0,05 yang artinya variabel daya tanggap tidak berpengaruh signifikan (parsial) terhadap kepuasan pelanggan pengguna apliaksi EMOS. Hal ini menunjukkan bahwa kecepatan yang dijanjikan oleh EMOS belum maksimal. Dalam penyelesaian masalah atau keluhan dari pelanggan membutuhkan waktu lama. Proses retur juga membutuhkan waktu yang lama karena pelanggan harus menunggu salesman datang dan mengisi form TTRB (Tanda Terima Retur Barang) yang kemudian dilanjutkan dengan mengambil barang retur.
Pengaruh Kontak $\left(\mathbf{X}_{6}\right)$ Terhadap Kepuasan Pelanggan Pengguna Aplikasi EMOS

Variabel kontak $\left(\mathrm{X}_{6}\right)$ dengan nilai $\mathrm{t}_{\text {hitung }}$ sebesar 2,795 lebih besar dari $t_{\text {tabel }}$ 1,66600, dan diperoleh nilai signifikan sebesar 0,007 dimana nilai tersebut lebih kecil dari nilai sig 0,05 yang artinya variabel kontak berpengaruh signifikan (parsial) terhadap kepuasan pelanggan pengguna aplikasi EMOS. EMOS memberikan informasi kontak yang dapat dihubungi oleh pelanggan apabila mengalami masalah dalam penggunaan aplikasi EMOS, pelanggan diberikan beberapa kontak alternatif yang dapat dihubungi, pelanggan dapat menghubungi salesman, ECC (Enseval Customer Care) atau menghubungi telepon kantor cabang Samarinda, bahkan pelanggan juga dapat melakukan panggilan langsung ke Customer Care EMOS yang terdapat pada halaman aplikasi.

Pengaruh E-Servqual (Y) Terhadap Kepuasan Pelanggan Pengguna Aplikasi EMOS

Variabel e-servqual yang meliputi efisiensi, reliabilitas, fullfilment, privasi, daya tanggap dan kontak dengan nilai $\mathrm{f}$ hitung sebesar 5,361 lebih besar dari $\mathrm{f}$ tabel sebesar 2,23, dan diperoleh nilai signifikan sebesar 0,000 dimana nilai tersebut lebih kecil dari nilai sig 0,05 yang 
artinya variabel efisiensi, reliabilitas, fullfilment, privasi, daya tanggap dan kontak berpengaruh signifikan secara bersama-sama (simultan) terhadap kepuasan pelanggan pengguna aplikasi EMOS. E-Servqual diterapkan oleh PT. Enseval Putera Megatrading, Tbk cabang Samarinda dalam meningkatkan pelayanan terutama pada layanan aplikasi EMOS

\section{KESIMPULAN DAN SARAN}

\section{Kesimpulan}

Berdasarkan hasil analisis dan pembahasan mengenai pengaruh e-service quality terhadap kepuasan pelanggan pengguna aplikasi EMOS pada PT. Enseval Putera Megatrading,Tbk cabang Samarinda dapat disimpulkan bahwa terdapat empat variabel yang tidak berpengaruh signifikan yaitu efisiensi, fulfillment, privasi dan daya tanggap, hal ini dikarenakan adanya permasalahan saat bertransaksi, adanya keterlambatan pengiriman, kekosongan stok, adanya kebocoran data pelanggan dan penanganan keluhan dan retur yang membutuhkan waktu lama. Sedangkan dua variabel yang berpengaruh signifikan yaitu reliabilitas dan kontak, hal ini karena EMOS memberikan keakuratan dalam pelayanan dan memiliki kontak alternatif yang dapat dihubungi secara online. Dapat dikatakan bahwa pelayanan yang diberikan kurang memberikan kepuasan kepada pelanggan sehingga harus ditingkatkan dan yang bertujuan untuk kepuasan pelanggan. Hal ini menunjukkan bahwa dimensi $e$ servqual memiliki peran penting dalam meningkatkan kepuasan pelanggan, dimana pelanggan dapat merasakan kemudahan, pelayanan yang cepat, informasi yang lengkap dan keamanan dalam bertansaksi dengan aplikasi EMOS.

melakukan evaluasi agar dapat memnigkatkan kualitas pelayanan dan menimbulkan adanya ekspektasi kepuasan pelanggan.

\section{Saran}

Berdasarkan hasil penelitian mengenai pengaruh e-servqual terhadap kepuasan pelanggan pengguna aplikasi EMOS pada PT. Enseval Putera Megatrading, Tbk cabang Samarinda, maka peneliti memberikan beberapa saran sebagai berikut:

1. Perlu adanya peningkatan e service quality dengan memaksimalkan seluruh pelayanan yang kurang memuaskan bagi pelanggan, terutama pada indikator efisiensi, fullfilment, privasi dan daya tanggap pada aplikasi EMOS. Selain itu PT. Enseval Putera Megatrading, Tbk cabang Samarinda memberikan evaluasi secara berkala terhadap pelayanan EMOS misalnya dengan memberikan kuesioner kepada 
pelanggan secara berkala untuk pertimbangan peningkatan pelayanan.

2. Selain peningkatan pelayanan dari keempat variabel tersebut, PT. Enseval Putera Megatrading, Tbk Cabang Samarinda juga harus mempertahankan pelayanan reliabilitas dan kontak yang sudah diterapkan pada aplikasi EMOS.

\section{DAFTAR PUSTAKA}

Alma, Buchari. 2013. Manajemen Pemasaran dan Pemasaran Jasa. Bandung: Alfabeta

Ghozali, Imam. 2009. Aplikasi Analisis

Multivariate dengan Program SPSS. Semarang: Badan Penerbit UNDIP. Imam. 2011. Aplikasi Analisis Multivariate Dengan Program IBM SPSS 19, Edisi Kelima. Semarang: Universitas

Diponegoro.
3. Dari hasil penelitian ini diharapkan dapat digunakan sebagai referensi bagi pihak kampus sebagai bahan acuan penelitian selanjutnya dalam melakukan penelitian yang berkaitan dengan keputusan pelanggan. Dengan menggunakan variabel tambahan lain yang berkaitan dengan e-service quality.

Nawawi. 2011. Manajemen Sumber Daya Manusia: Untuk Bisnis Yang Kompetitif. Yogyakarta: Gajah Mada University Press.

Suharno. 2017. Marketing in Pratice Edisi Ketiga. Samarinda: KP Books (Kaltim Post Group).

Sugiyono. 2016. Metode Penelitian Kuantitatif dan kualitatif $R \& D$. Bandung: Alfabeta.

Tjiptono, Fandy. 2017. Service Management: Mewujudkan Layanan Prima. Edisi Ketiga. Yogyakarta: Andi. 